\title{
Connecting with Students through a Critical, Participatory Curriculum: An Exploration into a High School History Teacher's Construction of Teacher-Student Relationships
}

\author{
Karla M. Zaccor ${ }^{1}$ \\ 1 Indiana University, Indianapolis, USA \\ Corresponding Author: Karla M. Zaccor, 902 W. New York St., Indianapolis, IN 46202, USA. \\ Email: kmzaccor@iu.edu
}

\begin{abstract}
:
Standardized testing is a top priority in schools, with conversations around teaching and learning reduced to raising student test scores. Often any other conversations about how schools should serve students are eliminated or pushed to the periphery. The central questions raised here are the following: how are student-teacher relationships constructed in the classroom and how important are those relationships to those students and teachers? My focal teacher enacted a curriculum that was critical and relevant to students' lives. He considered the curriculum as his primary way of building relationships with students.
\end{abstract}

\section{Keywords:}

Race, ethnography, urban education, cultural responsiveness, social, teacher- student relationships, critical curriculum

This is the author's manuscript of the article published in final edited form as: Zaccor, K. M. (2018). Connecting With Students Through a Critical, Participatory Curriculum: An Exploration Into a High School History Teacher's Construction of Teacher-Student Relationships. Urban Education, 0042085918794779. 


\section{CONNECTING WITH STUDENTS}

The current educational climate is obsessed with narrow, measurable outcomes - mainly standardized test scores. In schools deemed to be "failing" there is little discussion about anything other than what will move students forward on predictable, predetermined paths. This often fosters environments where student compliance is highly valued and strictly enforced. As school and district administration attempt to tightly regulate the instructional day, many teachers feel a lack of time and autonomy, and many students experience boredom, frustration, and alienation (Bartolomé, 1994; Lee, 1999; Nieto, 2003; Valenzuela, 1999).

Teacher-student relationships are not easily measured and are therefore not of primary concern to many participants in the national conversation on educational reform. For the purposes of this account, I am arguing that the kind of educational achievement that policymakers and their supporters claim to value cannot happen without taking teacher-student relationships into account. Additionally, I posit that easily measurable outcomes are not the sole determinant in education. We have decided that a "good" education is measured only by standardized test performance, but what about things like students feeling supported in and connected to school? What about ways that students and teachers can impact each other's lives that cannot be measured with a test?

Teaching is about more than delivering content to students. Effective teachers also demonstrate caring, believe in their students' abilities to learn, purposefully build relationships with students, learn about their students' lives outside of school, and show love and respect (Fisher, 2007; Foster, 1997; Ladson-Billings, 1995; Nieto, 2003, 2010).

This study, then, examines a context in which the environment looked and sounded different from the aforementioned description. Frustrated by working in places where attempts at forcing compliance comprised the primary way teachers interacted with students, I wanted to investigate what it could possibly look like to be in a classroom where teachers did care about building relationships with students while engaging them in an exploration of a relevant curriculum. I also wanted to know in what ways these relationships mattered to the teachers and students involved, if 


\section{CONNECTING WITH STUDENTS}

they mattered at all. It is my goal that this case study will add to a collection of stories about educational possibilities that better serve our students.

\section{Research Questions}

1. How does one $10^{\text {th }}$ grade United States history teacher construct relationships with his students in the classroom?

2. How do teachers and students view the role of teacher-student relationships in teaching and learning?

\section{Literature Review}

This work is situated in conversation with current research in urban education. I am joining conversations in current urban education research that include culturally responsive instruction (Brown-Jeffy \& Cooper, 2011; Dyson, 2003; Gay, 2000; Gay, 2014; Kirkland, 2014; LadsonBillings, 1995; Ladson-Billings, 2014; Paris, 2012; Paris \& Alim, 2014) as well as conversations about teaching in urban schools, specifically teaching Black students (Ferguson, 2000; Howard, 2013; Howard \& Milner, 2014; Noguera, 2008; St. John \& Cadray, 2004). This work adds to this research another window into what culturally responsive teaching can look like in an urban classroom, where students' racialized positioning in society is central to the curriculum. In order to define urban education in the context of this study, I borrow Milner's (2012) definition of "urban intensive," which he refers to as schools that are "concentrated in large, metropolitan cities across the United States" (p. 560).

\section{Caring Theory}

Noddings's (1984) theory on caring posits that relationships between teachers and students are central to the learning that happens in schools. Schools are primarily structured around aesthetic caring, which is attention to things and ideas rather than people (Eaker-Rich \& Van Galen, 1996; Gilligan, 1982; Noddings, 1984; Prillaman \& Eaker, 1994). Aesthetic caring is concerned with things like objectives, curriculum, and teaching strategies. Rolón-Dow (2005) explains, "Individuals 


\section{CONNECTING WITH STUDENTS}

who care aesthetically are committed to the school-sanctioned practices and behaviors believed to lead to educational achievement" (p. 86). These practices and behaviors are very narrowly defined. That is, aesthetic caring places value on a very limited range of behaviors. If students' behavior doesn't fall in this range, it means they do not care.

Rather than aesthetic care, caring theorists advocate for authentically caring relationships between teachers and students. Noddings (1984) argued that it is the responsibility of the teacher to initiate and cultivate these caring relationships and become engrossed in the students' lives. This means teachers must be concerned about students' lives both inside and outside of school. Noddings (1992) explained, "No matter how hard teachers try to care, if the caring is not received by students, the claim 'they don't care' has some validity" (p. 15). Different students may need to be cared for in different ways, or the same student on different days_-listening to students rather than deciding what is best for them is imperative for teachers (Garza, 2009; Noddings, 2005).

Caring theory, however, does not take issues of race, class, and power into consideration when talking about the way teachers need to care for students. Ignoring race means also ignoring the way racism reproduces the inequities students face in their daily lives. If we are unwilling to respond to the realities of our students' lives then we are not, in fact, caring for them. As RolónDow (2005) explained, caring theory "did not yield sufficient explanatory power as I sought to understand how the present sociocultural context and the racial relations therein affected caring and teacher-student relationships" (p. 86). Rolón-Dow advocates for "a race-centered critical care praxis that is relevant to marginalized groups of students within educational institutions" (p. 90). Roberts (2002) also described the need for "culturally relevant critical teacher care" for Black students in the United States (p. 454). The findings in this paper draw from Roberts and Rolón-Dow's ideas on critical care that is based on an understanding of students' racialized positioning in society. My findings add to their research by describing an instantiation of this concept of critical care in practice in a classroom. 


\section{CONNECTING WITH STUDENTS}

\section{Culturally Responsive Pedagogy}

Ladson-Billings (1994) explains that culturally relevant pedagogy (CRP) “uses student culture in order to maintain it and to transcend the negative effects of dominant culture" (p. 17). She goes on to say, "Culturally relevant teaching is a pedagogy that empowers students intellectually, socially, emotionally, and politically by using cultural referents to impart knowledge, skills, and attitudes" (p. 18). Freire and Macedo (1987) explain that educators "need to use their students' cultural universe as a point of departure, enabling students to recognize themselves as possessing a specific and important cultural identity" (p. 127). Culturally responsive (or relevant) teaching is an approach that affirms students' cultural identities and uses students' experiences, backgrounds, knowledge, and cultural practices as instructional tools in order to foster academic achievement (Foster, 1997; Gay, 2000; Ladson-Billings, 1994, 1995).

Freire repeatedly stated in many of his books that he was not looking to give educators a recipe. He said, "I cannot write a text that is filled with universal advice and suggestions" (Freire \& Macedo, 1987, p. 135). This is also true for culturally relevant pedagogy. One cannot become a culturally relevant teacher by adopting a specific set of practices. Milner (2011) explains that there is such diversity among students in different classrooms and different schools, there is no one approach that will work with all students. Milner emphasizes how important it is for teachers to build relationships with individual students as a way to make instruction culturally relevant for those particular students. Ware (2006), in a case study of two African American elementary school teachers, found that "relationship building was as important as teaching the subject matter" (p. 443). Pre-service teachers cannot be taught how to build relationships with their future students. Teacher educators can communicate to pre-service teachers the importance of building relationships, but there is no one way to do this.

One aspect of culturally relevant teaching is that teachers should be talking with students about racism and the prevalence of racism in the United States (Brown-Jeffy \& Cooper, 2011; 


\section{CONNECTING WITH STUDENTS}

Ladson-Billings, 2001). Ladson-Billings explains, "To prepare teachers to be successful with African American students, teacher educators must help prospective teachers recognize the ways that race and racism structure the everyday experiences of all Americans" (p. 211). Brown-Jeffy and Cooper discuss incorporating tenets of CRT into culturally relevant pedagogy. They argue that culturally relevant pedagogy "does not question or critically examine the structures that feed into the cultural incongruence perspective" (p. 71), i.e., the disconnections between home and school cultures that often exist for students of color and poor students. They argue that including a discussion of racism is critical for culturally relevant pedagogy. They explain, "The broadness of race (and consequently racism) can be seen in the way that it focuses specifically on how privilege has been given and truncated in American society, something culture does not do" (p. 71).

It is also not enough to affirm and celebrate difference. There needs to be discussion of issues of power as related to difference. These conversations can be difficult to have, especially considering the vast majority of teachers (who are white, middle class women) benefit from the existence of racism. Brown-Jeffy and Cooper (2011) explain, "In order for teachers to be culturally attuned to the identities of their students, they should be aware of their own identities" (p. 73). More thought needs to be put into how education programs can effectively incorporate antiracism into their coursework. Without critical awareness, schools will simply reproduce the inequalities that exist in greater society:

[If] teachers acknowledge that the system is racist, they can move forward to not only avoid socially reproducing the racism, but also to rethink the system, recognize their actions in it, change them if need be, and embrace all cultures as equally important. (Brown-Jeffy \& Cooper, p. 73)

This critical aspect was part of Ladson-Billings's (1995) original explanation of CRP, but as school systems and teacher education programs have adopted CRP, that aspect has been often left out. Ladson-Billings (2014) comments, "What state departments, school districts, and individual 


\section{CONNECTING WITH STUDENTS}

teachers are now calling 'cultural relevant pedagogy' is often a distortion and corruption of the central ideas I attempted to promulgate" (p. 82). The result has been a reimagining of sorts, which I describe below.

\section{Culturally Sustaining Pedagogy}

Paris (2012) and Paris and Alim (2014) propose looking at culturally relevant pedagogy with a new lens, that of a pedagogy aimed at sustaining students' languages and cultures. Paris argues that the way Ladson-Billings's (1995) conceptualization of culturally responsive pedagogy has been taken up by teacher education programs is a departure from the original intention, hence the need to reframe it. They argue that one aspect that has been missing from the ways culturally responsive pedagogy has been taken up is the critical component (Ladson-Billings, 2014; Paris, 2012; Paris \& Alim, 2014). Paris (2012) posits that responsive/relevant pedagogy is necessary, but it does not go far enough in supporting students' linguistic and cultural flexibility nor does it equip students with the tools to critique society's power structures. Paris and Alim (2014) also stress the dynamic nature of cultural practices. They state, "it is crucial that we understand the ways young people are enacting race, ethnicity, language, literacy, and cultural practices in both traditional and evolving ways" (p. 90). This reflects a definition of culture as not something that people are born into but rather as something that is both changing and reproducing as people engage in cultural practices (Irizarry, 2007; Paris, 2009; Rosaldo, 1989).

\section{Frameworks for Constructing Teacher-Student Relationships}

At a talk given by Pedro Noguera (2008, 2003), I heard a teacher comment that some of her students come to school with no background knowledge or experience. Noguera challenged her on this, to which the teacher responded, "Well, just not the kind of background knowledge I use in my classroom." The onus should be on the teacher to take the students' background and experiences into account. "If the child is to participate in the community of the teacher, then the teacher must be able to participate in the community of the child" (Hymes, 1972, p. xxxix). Teachers need to learn 


\section{CONNECTING WITH STUDENTS}

about their students and their lives outside of school. It is important to follow students' voices "into neighborhood corners and alley ways, off the beaten path of the curricular road, where the social action is" (Dyson, 1993, p. 7). This involves listening to students, asking about their lives, going places in the communities in which they live, rather than just making assumptions based on their race, class, etc. Teacher Mary Ginley explained her stance: "I have always spent time at the beginning of the year getting to know the children: talking to them, listening to them as they play, as they talk to their friends, as they try to tell me who they are" (Nieto, 2010, pp. 127-128).

Teachers must be familiar with students lives and find ways to bring aspects of their lives into the classroom. Moll and Gonzales (1994) define funds of knowledge "as those historically accumulated and culturally developed bodies of knowledge and skills essential for household or individual functioning and well-being" (p. 160). They documented literacy practices where students “borrowed from each other's experiences in making sense of the stories, relating them to their own lives, and evaluating the worthiness of the books" (p. 156). In this way, students' lives were welcomed into the classroom and used as building blocks to learning new content; explicit connections are made between students' home lives and school lives (Dyson, 2003). Alim and Smitherman (2012) discussed a classroom project where the students investigated language in their communities. Students conducted ethnographic research where their social lives "are not marginalized inside the classroom or left outside the door, but they are seen as valuable cultural and linguistic spaces for learning” (pp. 181-182). Joe, a high school English teacher in the Bronx, created the Power Writing class in order to use "reading, writing, and speaking . . . as a vehicle for enacting power over [students'] lives and futures" (Fisher, 2007, p. 3).

It is our responsibility to learn about the actual lives of our students, because "assumptions are made in educational institutions about the literacy needs of individual students which seem not to be borne out by the students' day-to-day lives” (Szwed, 1981, p. 427). As Dyson (2003) explained, "Like all learners, children must use familiar frames of reference (i.e., familiar practices) 


\section{CONNECTING WITH STUDENTS}

to make sense of new content, discursive forms, and symbolic tools" (p. 15). All children must be allowed the space to bring in their familiar frames to help them learn new concepts and content. As evidenced by the teacher's comment at the beginning of this section, some teachers have a very narrow view of what kinds of experiences are worthwhile to bring in to the classroom. As Joe explained to Fisher (2007), “My students' prior knowledge is profoundly respected by me and at some level exalted. This is not an attempt to colonize them. It is an attempt to extend on their natural learning capacity" (p. 13).

One effective pedagogical strategy is to organize instruction-especially literacy instruction —around dialogic instruction. Nystrand (1997) built on Bakhtin's (1981) theories about utterances being situated in particular contexts - individual utterances are responses to previous utterances as well as always anticipating future responses. In classrooms organized around dialogic instruction, meanings are constructed in the interactions between students and students and teacher. The teacher is not the authoritative voice, but one of many voices. As opposed to traditional instruction, where teachers transmit an already constructed body of knowledge to students, "dialogic instruction works by cultivating knowledge - transforming understandings through reflection and talk" (Nystrand, 1997, p. 26). Similarly, in looking at small group discussions, Chisholm and Godley (2011) found that "the discussion questions that promoted highly specific, personally relevant, and experiencedriven student responses . . led to richer engagement with sociolinguistic content knowledge than more general, hypothetical discussion questions" (p. 454). If we already know that learning is fundamentally social and students learn best when they can build from the known to the new, then organizing a classroom around dialogic instruction where students' knowledge is a valuable and necessary part of constructing new knowledge makes sense.

The thread that runs through all of the research in this section is not just a fundamental belief that all students can learn. Just as important is the belief that knowledge is constructed, rather than a static body that should be passed from teacher to students. Organizing a classroom where 


\section{CONNECTING WITH STUDENTS}

students' voices are legitimized and their contributions are valued is a critical component of this process. Teachers should also position themselves as co-learners, as people who also have "a wealth of life experiences from which he or she can draw, and is constantly challenging his or her own thinking about the world ... a practitioner of the craft ... a reader and writer" (Fisher, 2007, p. 14).

\section{Methods}

This project is a case study of one high school, with a closer look at one teacher and two of his classes. Because I am interested in the complexities inherent in classrooms and how broader socio-cultural issues influence classrooms and schools, I used ethnographic methods for this project (e.g., participant observation, open-ended interviews). The purpose of conducting ethnographic research is to figure out "what's happening here" and how participants make meaning out of what's happening (Dyson \& Genishi, 2005). This is all situated in a broader socio-cultural context, as well as a context that is co-constructed by my participants (in this case teachers and students). I have kept in mind "the task of the ethnographer is not to determine 'the truth' but to reveal the multiple truths inherent in others' lives" (Emerson et al., 1995, p. 3).

\section{Research Site}

Mandela High School ${ }^{1}$ is a small high school in Chicago, with 308 students in grades 9-12 at the time of the study. According to the district website, the student demographics at the time of the study were $81.8 \%$ Black, $11 \%$ Hispanic, $2.6 \%$ White, $2.3 \%$ Asian and $2.3 \%$ other. $95.8 \%$ of the students were considered low income, $24.4 \%$ received special education services and $7.1 \%$ were considered limited English proficient.

\section{Focal teacher}

Kurian Joseph is a history/social sciences teacher who has been teaching at Mandela for ten years. His first year of full time teaching was the first year Mandela existed. Kurian taught US History primarily to sophomores (there were some upper classmen in his classes either because they 


\section{CONNECTING WITH STUDENTS}

needed to make up a credit or they transferred into Mandela and had not taken the course before), and he also taught a Civics class for juniors and seniors. Kurian was born in suburban Chicago and then moved to a midsize city in the South. Both of his parents are immigrants, both from a part of Southern India that is Catholic.

\section{Data Collection Procedures}

I collected three major types of data: classroom observations and curriculum materials (i.e., classroom handouts/work), teacher interviews, and student interviews. I went to Mandela High School twice a week, on average, for four months. On the days I went to Mandela I attended two class periods of Kurian's US History class: $2^{\text {nd }}$ Period, which was his honors level class, and $3^{\text {rd }}$ Period, which was a regular level class (four class periods a week most of the weeks I was there). On the days I was there, I did not notice much of a difference in terms of the way the two classes were taught, either in teaching methods or content. The honors class had to do a little bit more homework than the regular class. I asked how decisions were made about which students go into honors class or regular classes and was told that the decisions are made by the student's same subject teacher their previous year. So, the freshman history teacher would have recommended students for Kurian's honors versus regular classes based on his perceptions of their effort and ability as well as their grades. Because Mandela High School was so small, sometimes adjustments were made for students in order to make their schedules work (e.g., logistical issues). During the time I was there, two students were transferred from Kurian's $5^{\text {th }}$ period class (regular level) to his $3^{\text {rd }}$ period honors class. I believe this happened due to a combination of the student expressing interest in taking honors classes and earning good grades during the first quarter.

I conducted participant observation in 42 class periods, totaling about 37 hours spent in the classroom. After leaving the field I wrote field notes, doing my best to tell a story reconstructing the classes' events using my notes and the audio-recording to jog my memory. 


\section{CONNECTING WITH STUDENTS}

I interviewed students from both classes in groups of two. This allowed me to interview more students in less time, and so students could build on each other's comments in conversation. The length of student interviews ranged between 30 and 45 minutes. I conducted six student interviews, with twelve students altogether. The interviewees were all sophomores; seven boys and five girls; five students were from the honors class and seven students were from the regular class.

I conducted three interviews with Kurian that were each about an hour long. Those interviews were semi-structured in that I had questions that I planned on asking him, but I also let the conversation take its natural course as well as asked additional questions based on the things that were said. The interviews were conducted roughly at the beginning, middle, and end of my data collection. All interviews were audio-recorded and transcribed.

\section{Data Analysis}

I applied grounded theory methods to my data analysis (Emerson, et al., 1995; Charmaz, 2010), meaning that I approached my initial analysis with no pre-set list of codes or themes. I attempted to "build ideas inductively" and tried to avoid "imposing extant theories or our own beliefs on the data" (Charmaz, 2010, p. 187). Many traditional interpretations of grounded theory "treat sets of already collected fieldnote data as unproblematic starting points; they implicitly assume that such fieldnotes can be analyzed independently of the analytic processes and theoretical commitments of the ethnographer who wrote them" (Emerson et al., p. 144). This is not what I attempted to do. Rather, I understand that my field notes are not "pure" and that my interview transcripts are responses to questions that I asked. My own perspective and ongoing analysis has been present in all stages of research. As the sole researcher on this project, all field notes, transcriptions, coding, and analysis was done by me.

I began my data analysis by reading over my entire corpus of data (field notes, interview transcripts), making notes in the margins as a way of trying to figure out what was happening. My goal in open coding was "to remain attuned to our subjects" views of their realities" (Charmaz, 


\section{CONNECTING WITH STUDENTS}

2010, p. 187). I first employed line-by-line coding in that I tried to code each chunk of data without thinking too much about how things connected to each other or to bigger themes (Saldaña, 2013). Once I went through my initial coding and wrote more analytic memos, I tried to look over my codes and see how things related and what things might be collapsed. From my collapsed codes I tested out a couple of assertions, writing vignettes and looking for data that would support or complicate my assertions (Erickson, 1986). I went through cycles of moving from my data to larger ideas and codes, and from those themes back down through my data. I wrote analytic memos throughout this process. I would move back and forth from my classroom field notes to my interview transcripts asking myself questions like how are the things participants said in interviews supported (or not) by the things that happened in the classroom?

\section{Role of the Researcher}

I have a long history with the school building, many of the staff members at the school, and the community. I grew up in the neighborhood and attended middle school in the building in which the school now exists. I have known several of the other teachers and faculty in the school for most of my life. My mother ${ }^{2}$ also teaches at the school and was one of the people on the design team for that school, along with two teachers I have known since I was a child.

I have thought a lot about my insider/outsider status at Mandela High School. I do not intend to downplay my privileged position as a white, middle class female graduate student. My insider status is connected to different aspects of my identity: my identity as a teacher and a community member. All aspects of one's identity do not carry equal status in society— the ways I identify as an insider do not reflect any sense of shared marginal status. Also, my insider status is considered with respect to the other teachers at Mandela, not the students. With the students I was an outsider in most ways - unfamiliar, white, from a university, and older. What mitigated my outsider status with

2 None of my research directly involved my mother. 


\section{CONNECTING WITH STUDENTS}

them was that several of their teachers knew me, which I'm sure helped the students feel more comfortable around me compared to if I would have been a stranger to everyone in the building.

While my role as "insider" definitely limits my perception, all perceptions are limited in some way(s). I believe it helps that I have worked in many different school buildings, so I have a keen sense of the different dynamics that exist in different buildings. I am not aiming for neutrality here-instead, my aim is to describe the way my participants experience and understand their world.

\section{Findings}

Ladson-Billings (2014) talked about many well-meaning teachers embracing aspects of culturally relevant pedagogy but missing key components. She said, "They rarely pushed students to consider critical perspectives on policies and practices that may have direct impact on their lives and communities. There was no discussion of issues such as school choice, school closings, rising incarceration rates, gun laws, or even everyday school climate questions like whether students should wear uniforms" (p. 78). This critical perspective was the focus of Kurian's classroom on a day-to-day basis. Rolón-Dow (2005) made a case for "critical care" and argued that many teachers are "not taking into account ... the political issues that matter in the lives of students of color" (p. 87).

In this section I will take an in-depth look at the different ways in which Kurian demonstrated Rolón-Dow's version of critical care. This particular version of critical care is central to the relationships described in this project. I argue that because Kurian's curriculum centered on critical issues that directly impacted his students, he cared for his students in a way that was meaningful beyond a surface-level, interpersonal relationship. Valenzuela (1999) asked, "What does it mean to care about children from marginalized communities, given the political and social context in which education takes place?" (p. xvi). I argue that Kurian demonstrated that he cared for his students 
CONNECTING WITH STUDENTS

through the enactment of a critical curriculum that centered on the social and political realities of his students' lives. 


\section{CONNECTING WITH STUDENTS}

\section{The Written Curriculum}

Kurian did not aim to teach US History from a traditional perspective (i.e., a linear review of major events). Throughout the year he designed opportunities for students to investigate how modern society is rooted in history as well as the entrenched nature of racism and oppression. Of the units he taught, the units I was present for during my data collection were especially centered on modern times, with a focus on issues students deal with on a regular basis. Before Kurian began his unit on mass incarceration he gave his students a survey asking if they had someone in their family as well as someone they are close to but not related to who had been in the prison system. Ninety to ninety-five percent of the students said yes to both questions, a clear indication that these issues are grounded in the lives of the students.

The teachers at Mandela were responsible for creating their own curriculum. They were not given any frameworks or units to modify. They were guided by the same mandates as other teachers_-pressures to raise standardized test scores as well as the almost universal adoption of the Common Core standards. Kurian was in a unique position because he taught an untested subject. But this does not mean he felt free from all pressure:

I'm in this classroom to teach a specific thing, right? And it's not, I mean, particularly the social justice stuff. Everything I teach matters. I believe kids HAVE to know this stuff. So I don't have time for chitchat, side conversations. I always feel like we HAVE to get through this stuff, we HAVE to know this, and so I'm gonna be about business the whole class, right?

Kurian made these comments to me specifically in the context of talking about how he relied heavily on his curriculum as a way of connecting with students, in contrast to other teachers who had reputations for interacting with students on a personal level more regularly. Kurian strongly 


\section{CONNECTING WITH STUDENTS}

believed in the importance of his curriculum and felt confident that because his curriculum was so directly related to his students' lives that he was able to connect with them primarily through the content of the class. At least to some extent, he was right. I asked Luis and Kendrick (focal students) what is it about teachers they like, why do they like the teachers they like?

Kendrick: I'm very comfortable with people from where I come from-people of my nation.

Researcher: You like Black teachers better, in general?

Kendrick: Not Black teachers.

Researcher: Okay.

Kendrick: - Because Robinson is not Black. Joseph is not Black. But they have that (pause) personality and that style OF (pause)

Researcher: Oh, okay so you're not saying race then?

Kendrick: It's not race.

Researcher: What is it?

Kendrick: I don't know, it's like-

Luis: It's the way that they-it's the way they understand him. It's like, they know where he's coming from, but they're not from where he's from.

Researcher: Okay.

Kendrick: Right. Like a cool—like I-grew-up-like-you type.

Kendrick felt like Kurian (Joseph) was able to understand him and where he's coming from; he even talked about communicating an "I grew up like you" type of understanding. What's interesting is that Kurian did not grow up "like" Kendrick. I asked Kurian how he felt like he was able to achieve this with his students: 


\section{CONNECTING WITH STUDENTS}

Kurian: I mean, especially compared to my students [I] grew up pretty privileged um, I think that was - uh you know, re-educating myself or (pause) yeah . . . And yeah, I mean it was through my own politicization, and that whole coming to consciousness thing and understanding oppression and why things are the way they are ... I think people who are you know, conservatives or liberals in the end, they at some level blame individuals for it . . But, I mean, my, the understanding I've come to - through my education and also just living in Chicago and working in schools is that I mean, there are bigger systems involved right? So I can’t—I don't blame any individual for what they do . . Like, I can't judge kids. And I know some of them are involved in the street, so I don't look down on them, uh, for that . . . So I mean, I come from a place of, I think of empathy, right? So whatever struggles or challenges kids are going through um, yeah I'm not coming from a place of judgment or I'm here to help you or save you, I have the answer if only you listened to me or act like me or whatever, then you'll be in the middle class and live the American dream kinda thing.

When I pressed him on how he thinks he communicates this understanding, this empathy to his students he said he does it through the content of the class. He designed a curriculum that is relevant to their lives and designs lessons so that students are able to participate and contribute. Kurian's view is that his curriculum does a lot of the work in terms of building relationships with his students. The curriculum, however, is not just his written unit plans but also the way his plans are enacted every day with his students.

\section{The Enacted Curriculum: Grounded, Critical and Participatory}

In this section the focus is on the enactment of his curriculum. I am going to explain how Kurian and his students co-constructed knowledge or contributed to the discussion, reaching a set 


\section{CONNECTING WITH STUDENTS}

of common understandings about the topic of the day-during his regular instruction time. This is not to say Kurian never gave notes or told them things because there were things that he knew that the students didn't (and vice versa). Kurian's curriculum was purposely designed to build on students' experiences. The tone that Kurian set in class was not one where he communicated that he knew things and the students should learn from him but rather he presented students with information that maybe they hadn't heard before. And guided them through discussion and exploration together to see how it might help them think about the issues in a different way.

In my attempt to describe the everyday happenings in his classroom, the hope is that the reader gets a sense of the culture that he and his students established, where opinions were shared and validated. The exchanges Kurian had with his students on a consistent basis demonstrated what he told me: for much of what they talk about in class, "the students are the experts in the room."

One of the lessons in the mass incarceration unit focused on how Black people are disproportionately arrested and convicted for marijuana possession. In the beginning of the lesson he wanted students to think about drug laws and why they exist in the first place. He put statements up on the board and had students move to different parts of the room depending on their level of agreement with the statement (strongly agree, agree, disagree, strongly disagree). The following discussion from $3^{\text {rd }}$ period is taken from my field notes:

The first statement Kurian puts up on the board is "People should not go to jail for smoking weed." All the students move to strongly agree and agree. There is a lot of talking going on as they move and once they get to their sections of the room. A boy says to another student, "Now you know you don't smoke."

Kurian goes to talk with students in their groups to find out their opinions. 


\section{CONNECTING WITH STUDENTS}

"Listen up listen up!" Kurian keeps trying to quiet everyone down. He wants them to have one conversation, people from different places share out. He says he's going to speak for strongly disagree since nobody is over there. He clarifies that he's just playing

devil's advocate. He says marijuana is illegal, so it would send a message that it's okay to do illegal things. It's a gateway drug, people will start using other drugs like crack and heroin and then ruin their lives.

Marcus says people smoke cigarettes, those are legal, and statistics show cigarettes will kill you more than weed.

Luis says you can't get addicted to it.

Davonte says, "Weed don't do nothing but keep you calm."

Another student says people should have a choice.

Kendrick says, "It's stress relief, especially for African Americans.” He adds that you can't OD on it and everyone does it.

Kurian puts the next statement up on the board. He tells them this one is different, it's about selling it, not smoking it.

The statement is "People should get locked up for selling weed."

The students move around.

There is lots of talking among the students again.

Krystal says that's how some people make their money.

Jamar says weed is good for you.

Omar says it's hard to find jobs; people are selling weed as a way to make money.

Elijah adds on that people are trying to support their families.

Another boy says if you're going to smoke it, where else are you going to get it from? 


\section{CONNECTING WITH STUDENTS}

LeShaun, in the agree section, says people might sell it to little kids or to the wrong people.

Elijah responds, "That's what's happening now."

Kendrick says it should be like other states where it's been regulated and sold in stores. Jamar says some kids start smoking at fourteen or under and start making bad decisions. This was a somewhat chaotic discussion even though it is not fully captured in my field notes because I tried to focus on the "official" talk. There were lots of side conversations happening, maybe because the students were excited to have marijuana as the topic for the day. I think Kurian got a little bit frustrated because he had a hard time quieting the class down so that there could be one conversation in which people shared out. As an observer it was clear to me that students had lots of opinions on marijuana laws and were excited to talk about them, probably because it was sprinkled with talk of their own usage. Kurian had designed this part of the lesson so student viewpoints were what mattered, and he also did not vilify them or pass moral judgment on drug use. The students clearly felt free to share their opinions. The focus of this lesson was on the unfairness of the drug laws and the unequal way they are enforced. He designed this unit to focus on a critical analysis and did not spend any time talking about the ills of drug use.

Another unit Kurian during my data collection was a unit focused on investigating the root causes of violence in Chicago. Chicago is often (falsely) referenced in the media as the murder capital of the United States. Many of the students believe this to be true-partly because they are exposed to the same media coverage as everyone else and partly because many of them live in neighborhoods where violence is commonplace. One day he passed out laminated maps of Chicago neighborhoods along with statistics from the city of Chicago on homicide rates- 


\section{CONNECTING WITH STUDENTS}

namely the neighborhoods with the highest homicide rates and the neighborhoods with the lowest homicide rates. Students found the neighborhoods on the map and marked them — the low homicide rates with circles and the high homicide rates with triangles (this revealed easy-to-see patterns between violent crime and neighborhood segregation). They then looked at other statistics for those neighborhoods_-poverty rates, unemployment rates, and per capita income. This is from the discussion they had at the end of class that day in $2^{\text {nd }}$ period:

Kurian asks, Why do you think the neighborhoods with high poverty, high unemployment, lower incomes have a lot of violence? Jamese says because they're unemployed, they spend a lot of time outside because they don't have anything else to do. Kurian said good point, they have a lot of free time so, you're outside. "Somebody build on that."

Samantha says when they're outside they get involved with gangs and do something illegal to make money because you don't have a job.

Kurian asks was this question fairly obvious to them? There is a chorus of yeses. He says for a lot of people the answer is not that obvious. He asks if they remember the day in class where they looked at the comments people left on YouTube. Several students say yeah, they remember. He said they don't put those pieces together-they say what's wrong with the Black parents in these neighborhoods, why don't they raise their kids right? They don't see the connections on all these levels.

Kurian goes on to say, so when someone gets killed and you see the suspect's face on the news, we just see the individual and think oh, they're a bad person because they murdered someone. The rest of all this is not obvious. Even some of the people who live 


\section{CONNECTING WITH STUDENTS}

in these neighborhoods don't put the pieces together. You gotta look deeper to see why do people do what they do.

We gotta get other people to understand this stuff too. I don't hear a lot of talk about fixing up neighborhoods. I hear a lot of talk about more cops. But I don't hear anybody talking about we need more jobs in these neighborhoods, we need higher incomes. A lot of people don't get this or they choose to ignore it.

The students understood the link between unemployment, high concentrations of poverty, and participation in gangs and other illegal activity. Kurian wanted the students to see how their understanding pushes back against the way much of mainstream society defines "the problem" of violence as well as the proposed solutions.

Kurian and his students worked together in class to come to a critical understanding about issues that directly impact their lives. He wanted students to have the tools to engage in critical analysis. He told them flat out, "I'm teaching you this stuff so you can change it. Not just so you can be smart and impress your friends with how much you know about the world, but so we can actually try and do something." Kurian did not position himself as the expert in the room but rather as a facilitator and participant. Student contributions were sought out and valued. Rather than pushing his own analysis onto them, Kurian created space for students to draw their own conclusions.

In addition to incorporating students' ideas and experiences regularly during his planned lessons, Kurian also did not shy away from discussing things that were going on in the world. That was made evident to me on November 25, the day after the announcement that police officer Darren Wilson would not be indicted for the murder of Mike Brown in Ferguson, Missouri. This is from my field notes from $2^{\text {nd }}$ period: 


\section{CONNECTING WITH STUDENTS}

The classroom is buzzing with conversation. Students are talking to each other, or commenting to no one in particular their outrage and disbelief, "that's bogus" and "how many more times?" Mimi says, "I feel like no matter how much we protest, things don't change." Students murmur responses. Kurian asks the class, how many people agree? We see things like this happen over and over again and a lot of people end up feeling that way. Isaiah exclaims: "I don’t agree!" Kurian goes on to say, "How many more Trayvon Martins? How many more Jordan Davises? How many more Mike Browns until things change?" Then, in response to Isaiah he asks him, so what gives you hope? Isaiah explains that the protests show that people aren't going to just sit around and take it. Kurian responds, so the question is, what do WE have to do and what are WE going to do together to change things? The students, still fired up, call out things like: "Kill all the police officers" and "If this happens again, I swear." Kurian responds that anger is a valid response, but it won't get us very far because the police will always be more powerful. So how do we actually make real changes? And talks about how there have been increased voter registration efforts in Ferguson so they can elect new people and have more community representation in local government. He adds on that here in Chicago there are organizations working against police brutality that he can connect them to if they are interested. He explains that the group just went to the United Nations, so there is stuff happening in Chicago that they can get involved with.

Kurian scrapped whatever plans he had for the day and devoted the classes to discussing what happened and what can happen next. Kurian created a space for students to express their unfiltered responses and discuss any confusion about the grand jury procedure. His consistent charge to them was what can we do? How can we work to change things? As an observer, sitting 


\section{CONNECTING WITH STUDENTS}

in on classes on this day was very powerful. Students were outraged - and that outrage was welcomed. They watched video footage of people protesting in Ferguson and a protestor said, "At the end of the day black lives don't matter." Mimi called out, “They sure don't! I agree with that!" Here is more of the conversation from that day:

A couple of girls start asking about Obama, asking what is he doing. Kurian said Obama came on TV last night. Jamese said, "He always saying something, not doing nothing!" Kurian tells them Obama said we need to fix the mistrust between the police and communities of color, but that we need to respect the decision of the grand jury and not do anything violent.

Jamese said, "Hell naw!"

Mimi says she wonders do any Chicago police officers feel like what Darren Wilson did was right?

Kurian tells her to ask Officer Johnson (the Chicago police officer who is assigned to Mandela). Kurian said when they go down to lunch they should ask him. Mimi says, well Officer Johnson is Black. She means a white police officer.

Kurian says you'd be surprised. His wife has a friend who's a cop (and black) and he was arguing for Darren Wilson, saying he had a right to kill Mike Brown. So just because people are Black or white doesn't mean you can guess how they think. Another girl says she's going to ask Officer Johnson.

LaChyrell says nothing has changed just because we have a Black president. Mimi says we need to be heard!

Kurian says, "all right! Let's make a plan!"

Mimi says, "Where Rahm Emanuel at?" 


\section{CONNECTING WITH STUDENTS}

LaChyrell says Obama's words go in one ear and out the other. Nobody changes anything just because he said something.

Kurian tries to talk over the kids (who are still talking about this, no off-topic conversations). He says two points about Obama, one is he's been President for a while now. He says he voted for him in '08 expecting some change. Jamese says, "You thought he was gonna do something." Kurian goes on to say, "I was naïve to think that was going to happen. I don't know his own personal beliefs about this. Either he feels one way privately but because of his position he has to watch what he says OR he says exactly what he believes." The second thing, he says, is that as president, we think of him as allpowerful. But in terms of the Ferguson police department he can't do anything himself. He can ask the attorney general to get involved, but he doesn't have any direct power. He can't fire the police chief or anything like that, he can't do that. And then the second question: Is it really in his heart to do anything about it? That's something we need to figure out.

Mimi says, "We need to take a trip!"

Kurian says, "One thing we can learn in this class is don't expect any politician to save you. Don't expect Obama to save you."

A girl says, "They not gonna listen to us!"

Kurian says, that's not how things change. "Things change when, what Mimi's talking about —when YOU want to change them."

Mimi says, "Right!"

Several kids are getting amped up. "That's what I'm saying!" Some students are clapping. Mimi says something about tearing this mug up. 


\section{CONNECTING WITH STUDENTS}

This day in class was very much an eye-opener for me. This was the first day I heard Kurian make such strong statements about his own personal beliefs as well as the statements he made about the purpose of the class overall ("what are WE gonna do to change things?"). The students were also very interested in the discussion. When Kurian passed out the paper that had an explanation of the grand jury proceedings Jamese shushed her classmates and told them she wanted to read. Mimi left the class saying she was going to bring this up in her other classes. Kurian did not shy away from discussing what was going on in the world, nor did he try to control the direction of the discussion. He allowed students to talk about things the way they wanted, and responded organically to them rather than pushing an agenda — aside from his push towards action.

Kurian created space for his students to express opinions, ask questions, and talk together. These things were built in to his lessons on a daily basis, but there were times when the regularly scheduled plans were adjusted. Here is another similar instance from my field notes, from the first day back after Thanksgiving Break in $3^{\text {rd }}$ period. Kurian took some time at the beginning of class to discuss news from over the break, including new facts that emerged about Darren Wilson's version of the story:

Kurian explained that what he heard on the news is according to Darren Wilson there was some kind of conflict in the car; Mike Brown was hitting and punching him. Jamar asked, incredulously, "Why would somebody fight a cop?” and muttered that that makes no sense.

Another student then asked, so then how did he get shot?

Kurian mentioned that there is conflicting testimony about what happened.

Davonte said, wasn't he with his friend? He thought his friend said what happened too. 


\section{CONNECTING WITH STUDENTS}

Kurian said he doesn't know what went wrong with the grand jury. The stories don't match up, "that's the troubling part." Then he added, "and Michael Brown doesn't get to defend himself." Kurian then asked the class if they heard about the twelve-year-old boy who got killed (Tamir Rice). A few students said yeah. Kurian said, "Supposedly they thought he was in his twenties.” Marcus said, “Don’t no twelve-year-old look like a twenty-year old!"

Kurian added that he got shot within three seconds of the police pulling up, and said that's not even enough time for him to hear the cops and put the gun down. Marcus is in disbelief. "Like, do they ever say freeze anymore? They just shoot?" Kurian said it's another crazy story. And hopefully it'll build some momentum and people will want to do something about it.

A of couple students make comments about how crazy it is for the police to just shoot. Kurian agreed, and said yeah, and they don't do that for other people. Somebody jumps over the White House fence and he just gets arrested, not shot. Clearly, race is a factor with the twelve-year-old too. If the boy would have been white, it probably wouldn't have gone down like that.

There are several aspects of this exchange that are interesting. The students were clearly expressing that they found it extremely difficult to believe the police's versions of both stories. Students understand how exchanges with the police often go, which is why Jamar was very skeptical about Darren Wilson's version of the story. Kurian not only affirmed these opinions but he also added additional information to support what they were saying. Based on the comments from the students, Kurian was correct in assuming that this was something important enough to discuss, even if it wasn't part of the plan for the day. He also let the students determine the 


\section{CONNECTING WITH STUDENTS}

direction of the conversation. During $2^{\text {nd }}$ period, the conversation took a different route because students brought up a connection to the Jordan Davis case and had questions for Kurian about that. So even though Kurian asked both classes about what updates they had heard about Darren Wilson and Tamir Rice over the weekend, the students in the classes largely determined the direction of the conversations.

Kurian wanted to talk about these issues openly in class and also expressed the hope that people will take action to try and change things. Kurian consistently had conversations with his students about the role of racism in society - much of his curriculum was structured around the notion that racism is endemic in American society.

\section{Discussion and Conclusion}

Kurian was countering the dominant way US History gets taught—which is linear and generally a story of progress (i.e., the United States used to do some bad stuff, but look how much better it's gotten!). The bulk of his course while I was there was focused on current problems that students have personal experience with (mass incarceration/criminalization, economic inequality), and he tied those social problems to a history of racism and capitalism. Rolon-Dów (2005) argued that "to care for students of color in the United States, we must seek to understand the role that race/ethnicity has played in shaping and defining the sociocultural and political conditions of their communities" (p. 104). This is exactly what Kurian did on a daily basis in his US History classroom.

According to Valenzuela (1999), "to make schools truly caring institutions for members of historically oppressed subordinate groups ... Students' cultural world and their structural position must also be fully apprehended, with school-based adults deliberately bringing issues of race, difference, and power into central focus" (p. 109). The way Kurian's curriculum was 


\section{CONNECTING WITH STUDENTS}

enacted in the classroom embodies the kind of teaching Valenzuela called for. Kurian communicated to his students that he cared about them and respected their agency through the topics they discussed in class and the way they discussed them. This made students feel connected to him and his class. Davonte told me, "He actually a fun, cool teacher . . . cuz the stuff that he teach and stuff." That Kurian talked with his students about drug use and gangs without the typical "just say no" mentality that is typical of many adults is important. This contributed to students feeling like Kurian understood where they were coming from-even though he did not grow up in similar circumstances.

Researchers have revisited culturally relevant pedagogy and reiterated the need for teaching practice that includes a critical examination of society's power structures and also sustains students' cultures (Ladson-Billings, 2014; Paris, 2012; Paris \& Alim, 2014). This research documents the practices of a teacher who is trying to do those things in his classroom. One aspect of building relationships with students is teachers' successfully communicating to students that they care about their lives inside and outside school (Noddings, 1984). For Kurian, this was primarily accomplished by creating and enacting a curriculum that was critical, relevant and drew heavily on students' ideas and experiences. Where most of the research documented instances where schools largely felt like uncaring places and students felt alienated, the students I talked to at Mandela felt like their teachers really cared about them (Lee, 1999; Rolón-Dow, 2005; Valenzuela, 1999). Fisher's (2007) and Antrop-González and DeJesús’s (2006) research both document instances where teachers cultivated caring relationships but in non-traditional contexts (i.e., not in traditional K-12 public school settings). For these reasons I position my work as research that is intentionally in dialogue with the aforementioned studies in that it 


\section{CONNECTING WITH STUDENTS}

focuses on the construction of the kind of teacher-student relationships that the research says is necessary for students in traditional public school contexts.

The importance of who Kurian is outside of his classroom became clear in my data collection and analysis. When other researchers have argued that teachers need to care for their students in ways that take into account students' marginalized positions in society (i.e., in ways that are not color blind) they did not talk about how teachers might arrive at a place to be able to do that (Rolón-Dow, 2005; Valenzuela, 1999). Kurian brings a critical consciousness to teaching, demonstrated in his ability to foster relationships with his students that were caring and take into account their position in a racist society. Reflective of his belief system, teaching is his way to participate in a movement for radical social change. In his classroom he was able to practice the kind of critical caring that Rolón-Dow called for, due to his commitment to bring a critical consciousness to teaching. However, I am not arguing that being critically conscious prior to becoming a teacher is the only way these critical relationships can happen. But in order for teachers to address the role of racism and power structures in the lives of their students they must first have a thorough understanding of these structural things themselves.

\section{Implications for Teacher Education}

As stated in the previous section, in order for teachers to care about Black and other minoritized students they need to understand the ways structural racism operates in schools, educational policies, and in society overall (Ladson-Billings, 2014; Paris, 2012; Paris \& Alim, 2014; Rolón-Dow, 2005; Valenzuela, 1999). This necessitates a purposeful focus in teacher education programs across all courses, not just as an add on class. Hayes (2008) also calls for a focus on "nurturing pedagogy" in teacher education programs for teachers of young children (p. 436). I would argue that this focus on caring for students (e.g., caring in the ways described 


\section{CONNECTING WITH STUDENTS}

earlier in this article) is a large part of the job of a teacher of any age students, not just teachers of young students. This would also require adjusting the focus of teacher education programs holistically in a way that conceptualizes teaching as more than delivering content to students and managing classrooms.

There are no recipes in teaching or teacher education. Stories are powerful teaching tools,

however. My goal is that this research adds to a body of stories about classrooms and teachers so that pre-service teachers can see the realm of possibilities and carve out their own practice of teaching in ways that affirm and sustain students' cultures and knowledge as well as pushes towards a critical understanding of our world. 


\section{CONNECTING WITH STUDENTS}

\section{References}

Alim, H. S. \& Smitherman, G. (2012). Articulate while Black: Barack Obama, language, and race in the U.S. New York, NY: Oxford University Press.

Antrop-González, R. \& DeJesús, A. (2006). Toward a theory of critical care in urban small school reform: Examining structures and pedagogies of caring in two Latino communitybased schools. International Journal of Qualitative Studies in Education, 19(4), 409-433.

Bakhtin, M. (1981). The dialogic imagination. Austin, TX: University of Texas Press.

Bartolomé, L. I. (1994). Beyond the methods fetish: Towards a humanizing pedagogy. Harvard Educational Review, 64(2), 173-194.

Brown-Jeffy, S. \& Cooper, J. E. (2011). Toward a conceptual framework of culturally relevant pedagogy: An overview of the conceptual and theoretical literature. Teacher Education Quarterly, 38, 65-84.

Charmaz, K. (2010). Grounded theory: Objectivist and constructive methods. In W. Luttrell (Ed.), Qualitative educational research: Readings in reflexive methodology and transformative practice, pp. 183-207. New York, NY: Routledge.

Chisholm, J. S. \& Godley, A. J. (2011). Learning about language through inquiry-based discussion: Three bidialectal high school students' talk about dialect variation, identity, and power. Journal of Literacy Research, 43(4), 430-468.

Dyson, A. H. (2003). The brothers and sisters learn to write: Popular literacies in childhood and school cultures. New York, NY: Teacher's College Press.

Dyson, A. H. (1993). The social worlds of children learning to write in an urban primary school. New York, NY: Teachers College Press. 


\section{CONNECTING WITH STUDENTS}

Dyson, A. H., \& Genishi, C. (2005). On the case: Approaches to language and literacy research. New York: Teachers College Press.

Eaker-Rich, D. \& Van Galen, J. A. (1996). Introduction. In D. Eaker-Rich \& J. A. Van Galen (Eds.), Caring in an unjust world: Negotiating the borders and barriers in schools, pp. 110. Albany, NY: State University of New York Press.

Emerson, R. M., Fretz, R. I., \& Shaw, L. L. (1995). Writing ethnographic fieldnotes. Chicago, IL: University of Chicago Press.

Erickson, F. (1986). Qualitative methods in research on teaching. In M. C. Wittrock (Ed.), Handbook of Research on Teaching, pp. 119-161. Washington, DC: American Education Research Association.

Ferguson, A. (2000). Bad boys: Public schools in the making of Black masculinity. Ann Arbor, MI: University of Michigan Press.

Fisher, M. (2007). Writing in rhythm: Spoken word poetry in urban classrooms. New York, NY: Teacher's College Press.

Foster, M. (1997). Black teachers on teaching. New York, NY: New Press.

Freire, P. \& Macedo, D. (1987). Literacy: Reading the word and the world. South Hadley, MA: Bergin and Garvey.

Garza, R. (2009). Latino and white high school students' perceptions of caring behaviors. Urban Education, 44(3), 297-321.

Gay, G. (2000). Culturally responsive teaching: Theory, research and practice $\left(2^{\text {nd }} \mathrm{Ed}\right) . \mathrm{New}$ York, NY: Teachers College Press. 


\section{CONNECTING WITH STUDENTS}

Gay, G. (2014). Culturally responsive teaching principles, practices, and effects. In H. R. Milner \& K. Lomotey (Eds.), Handbook of Urban Education, pp. 353-372. New York, NY: Routledge.

Gilligan, C. (1982). In a different voice. Cambridge, MA: Harvard University Press.

Hayes, N. (2008). Teaching matters in early educational practice: The case for a nurturing pedagogy. Early Education and Development, 19(3), 430-440.

Howard, T. C. (2013). How does it feel to be a problem? Black male students, schools, and learning in enhancing the knowledge base to disrupt deficit frameworks. Review of Research in Education, 37(1), 54-86.

Howard, T. C. \& Milner, H. R. (2014). Teacher preparation for urban schools. In H. R. Milner \& K. Lomotey (Eds.), Handbook of Urban Education, pp. 199-216. New York, NY: Routledge.

Hymes, D. (1972). Introduction. In C. Cazden, D. Hymes, \& V. P. John (Eds.) Functions of Language in the Classroom. pp. xi-lvii. New York: Teachers College Press.

Irizarry, J. (2007). Ethnic and urban intersections in the classroom: Latino students, hybrid identities, and culturally responsive pedagogy. Multicultural Perspectives, 9(3), 21-28.

Kirkland, D. E. (2014). Urban Literacy Learning. In H. R. Milner \& K. Lomotey (Eds.), Handbook of Urban Education, pp. 394-412. New York, NY: Routledge.

Ladson-Billings, G. (2014). Culturally relevant pedagogy 2.0: a.k.a. the remix. Harvard Educational Review, 84(1), 74-84.

Ladson-Billings, G. (1995). Toward a theory of culturally relevant pedagogy. American Educational Research Journal, 32, 465-491. 


\section{CONNECTING WITH STUDENTS}

Ladson-Billings, G. (1994). The dreamkeepers: Successful teachers of African American children. San Francisco, CA: Jossey-Bass.

Lee, P. W. (1999). In their own voices: An ethnographic study of low-achieving students within the context of school reform. Urban Education, 34(2), 214-244.

Milner, H. R. (2012). But what is urban education? Urban Education, 47(3), 556-561.

Milner, H. R. (2011). Culturally relevant pedagogy in a diverse urban classroom. Urban Review, 43, 66-89.

Moll, L. \& Gonzales, N. (1994). Lessons from research with language-minority children. In E. Cushman, E. R. Kintgen, B. M. Kroll, \& M. Rose (Eds.) Literacy: A critical sourcebook. pp. 156-171. Boston, MA: Bedford/St. Martin’s.

Nieto, S. (2010). The light in their eyes: Creating multicultural learning communities. New York, NY: Teachers College Press.

Nieto, S. (2003). What keeps teachers going? New York, NY: Teachers College Press.

Noddings, N. (2005). The challenge of care in schools: An alternative approach to education $\left(2^{\text {nd }}\right.$ ed.). New York, NY: Teachers College Press.

Noddings, N. (1992). The challenge to care in schools: An alternative approach to education. New York, NY: Teachers College Press.

Noddings, N. (1984). Caring: A feminine approach to ethics and moral education. Berkeley, CA: University of California Press.

Noguera, P. (2008). The trouble with Black boys: And other reflections on race, equity, and the future of public education. San Francisco, CA: Jossey-Bass.

Noguera, P. (2003). City schools and the American dream: Reclaiming the promise of public education. New York, NY: Teachers College Press. 


\section{CONNECTING WITH STUDENTS}

Nystrand, M. (1997). Opening dialogue: Understanding the dynamics of language and learning in the English classroom. New York, NY: Teachers College Press.

Paris, D. (2012). Culturally sustaining pedagogy: A needed change in stance, terminology and practice. Educational Researcher, 41(3), 93-97.

Paris, D. (2009). “They're in my culture, they speak the same way”: African American Language in multiethnic high schools. Harvard Educational Review, 79, 428-447.

Paris, D. \& Alim, H. S. (2014). What are we seeking to sustain through culturally sustaining pedagogy? A loving critique forward. Harvard Educational Review, 84(1), 85-100.

Prillaman, A. R. \& Eaker, D. J. (1994). The weave and the weaver: A tapestry begun. In A. R. Prillaman, D. J. Eaker, \& D. M. Kendrick (Eds.), The tapestry of caring: Education as nurturance pp. 1-11. Norwood, NJ: Ablex.

Roberts, M. A. (2010). Toward a theory of culturally relevant critical teacher care: African American teachers' definitions and perceptions of care for African American students. Journal of Moral Education, 39(4), 449-467.

Rolón-Dow, R. (2005). Critical care: A color(full) analysis of care narratives in the schooling experiences of Puerto Rican girls. American Educational Research Journal, 42(1), 77111.

Rosaldo, R. (1989). Culture and truth: The remaking of social analysis. Boston, MA: Beacon Press.

St. John, E. P., \& Cadray, J. P. (2004). Justice and care in postdesegregation urban schools: Rethinking the role of teacher education programs. In V. Siddle Walker \& J. R. Snarey (Eds.), Race-ing moral formation: African American perspectives on care and justice, pp. 93-110. New York, NY: Teachers College Press. 


\section{CONNECTING WITH STUDENTS}

Saldaña, J. (2013). The coding manual for qualitative researchers ( $\left.2^{\text {nd }} E d\right)$. Los Angeles, CA: Sage.

Szwed, J. F. (1981). The ethnography of literacy. In E. Cushman, E. R. Kintgen, B. M. Kroll, \& M. Rose (Eds.) Literacy: A critical sourcebook. (pp. 421-429). Boston, MA: Bedford/St. Martin's.

Valenzuela, A. (1999). Subtractive schooling: U.S.-Mexican youth and the politics of caring. Albany, NY: State University of New York Press.

Ware, F. (2006). Warm demander pedagogy: Culturally responsive teaching that supports a culture of achievement for African American students. Urban Education, 41, 427-456. 